2. Вакалюк, Е.С. Криминологическая характеристика матери-убийцы / Е.С. Вакалюк // Научное обозрение. Серия 2: Гуманитарные науки. 2012. № 5. С. 197-201.

3. Натура, А.И., Злобина, Л. А. Социально-психологический статус матери-убийцы новорожденного ребенка как элемент криминалистической характеристики преступления / А.И. Натура, Л. А. Злобина // Теория и практика общественного развития. 2017. № 12. С. 134-138.

4. Резник, Ж.Я. Социально-психологический и демографический статус матери - убийцы новорожденного ребенка как элементы криминологической характеристики личности / Ж. Я. Резник // Вестник Самарского юридического института. 2018. №5. С.131-135.

5. Середа, Е.В. Применение наказания в виде лишения свободы в отношении женщин: учебное пособие / Е.В. Середа. Рязань: Изд-во Рязан. ин-та права и экономики и права, 2000. 50 с.

6. Портал правовой статистики Генеральной прокуратуры Российской Федерации [Электронный pecypc]. Режим доступа: https: // crimestat.ru/ Загл. с экрана.

\title{
Пузиков С.А. \\ Особенности правового регулирования отношений, возникающих в сфере технического обслуживания внутридомового газового оборудования (ТО ВДГО)
}

Волгоградский государственньй университет (Россия, Волгоград)

doi: 10.18411/lj-04-2021-244

\section{Аннотация}

В статье кратко рассмотрены отдельные проблемные вопросы, связанные с недостатками законодательного регулирования деятельности по техническому обслуживанию внутридомового газового оборудования

Ключевые слова: внутридомовое газовое оборудование, газоснабжение, специализированные организации.

Keywords: indoor gas equipment, gas supply, specialized organizations.

Техническое и аварийно-диспетчерское обслуживание внутридомового газового оборудования, являясь необходимым элементом процесса газоснабжения, фактически производились с момента начала массовой газификации в СССР, начиная со второй половины XX века. Тем не менее, первое упоминание о договоре о техническом обслуживании внутридомового газового оборудования и аварийно-диспетчерском обеспечении (далее договор о ТО ВДГО) в нормативном акте, принятом на уровне Правительства РФ, содержится в Правилах поставки газа для коммунально-бытовых нужд граждан (Правил), утвержденных Постановлением Правительства РФ № 549 от 21.07.2008г. Возможно, что принятие Правил было продиктовано необходимостью изменения негативных тенденций, сложившихся в сфере газоснабжения населения в связи с проводимыми в двухтысячные годы реформами, в результате которых реализация газа населению была отделена от эксплуатации и технического обслуживания внутридомового газового оборудования, а обязанность по его поддержанию в надлежащем техническом состоянии возложена на собственников оборудования - физических лиц. В результате неисполнения собственниками указанных обязанностей, в целом по Российской Федерации и в Волгоградской области, в частности, продолжает фиксироваться значительное количество инцидентов и аварийных ситуаций, связанных с использованием газового оборудования в быту, в том числе с человеческими жертвами. Информация об этом закрытой не является и регулярно появляется на страницах федеральных и региональных СМИ. Ситуация оказалась настолько острой, что Правительство РФ постановлением от 14.05.2013 N 410 утвердило Правила пользования газом в части обеспечения безопасности при использовании и содержании внутридомового и внутриквартирного газового 
оборудования. Однако, как показала практика, предложенная Правительством РФ модель правового регулирования рассматриваемых отношений, не достигла своей главной цели: безопасное и безаварийное использование газа в бытовых целях. Изначально Правила предполагали, что указанной деятельностью должны заниматься исключительно газораспределительные организации, т.е. организации, занимающиеся транспортировкой газа потребителям. Свою позицию Правительство РФ аргументировало тем, что именно газораспределительные организации имеют обученный персонал и аварийные службы, большой опыт и ресурсы (т.е. заинтересованы в качестве услуги т.к. способны нести реальную имущественную ответственность перед потребителями). Однако Верховный Суд РФ, с подачи антимонопольной службы, решением от 10.12.2013г. № АКПИ13-826 признал недействующими сразу 16 пунктов Правил, касающихся упоминания газораспределительных организаций, указав, что Правительство не вправе принимать решений, ограничивающих конкуренцию (по данному вопросу необходимо принимать решения на уровне федерального закона) [1]. Однако столь необходимый закон до настоящего времени так и не принят. В результате этого, в настоящее время сложившейся ситуацией не удовлетворены все субъекты регулирования, участвующие в процессе. Потребители услуги не довольны стоимостью услуги (стоимость выведена из сферы государственного регулирования цен), минимальным объемом работ, предусмотренных Правилами (по сути лишь профилактический осмотр), большим количеством никем не контролируемых организаций, предоставляющих указанные услуги, зачастую невысокого качества. Исполнители услуг, прежде всего газораспределительные организации также недовольны тем, что на ставшем конкурентом рынке появилось значительно количество недобросовестных участников. К этому привело в значительной степени отсутствие каких-либо минимальных требований к субъектам, осуществляющим деятельность (определен лишь уведомительный порядок органов жилнадзора о начале деятельности, госорган в данной части наделен лишь функциями статиста по ведению на своем сайте реестра организаций, прим. на территории г. Волгограда несколько десятков). Субъекты малого предпринимательства (в т.ч. индивидуальные предприниматели) выедены изпод общего контроля в силу своего статуса, а основные проверки проводятся в отношении газораспределительных организаций. Недобросовестная конкуренция приводит к тому, что новостройки обслуживаются субъектами малого предпринимательства, a изношенный жилищный фонд обслуживают газораспределительные организации, у которых нет свободы выбора. При этом, аварийные ситуации, связанные с использованием газа в быту, продолжаются. Последняя трагедия со смертельным исходом в Волгограде, указанная в СМИ (ул. Санаторная, новостройка) является характерной [2]: исполнитель - мелкая организация с уставным капиталом в несколько тысяч рублей не понесет реальной имущественной ответственности, дело ограничится лишь приговором в отношении физического лица.

Надзорные органы (прежде всего жилищный надзор) также нельзя назвать удовлетворенными существующим Правилами. Массовые нарушения в рассматриваемой сфере деятельности продолжаются, а введенная в КоАП РФ статья 9.23 предусматривающая ответственность за нарушение правил обеспечения безопасного использования внутридомового газового оборудования по сути должным образом не работает. В значительной степени, такая ситуация стала возможной из-за трудно исполнимой уведомительной процедуры, прописанной в Правилах относительно действий организации - исполнителя в отношении недобросовестных потребителей, которая не только неоправданно длительна (что в газоснабжении недопустимо), но и чрезмерно обременительна для реального исполнения 
(необходимость неоднократных уведомлений, согласований и т.д. с абонентами, в том числе недобросовестными). Указанная ситуация создает условия для недобросовестно поведения и не может оцениваться как оптимальная.

Очевидно, что необходимость дальнейшего развития процесса правового регулирования отношений, возникающих в сфере технического обслуживания внутридомового газового оборудования населения сомнений не вызывает. При этом необходимо учесть допущенные в прошлые периоды ошибки, а не пытаться «зарегулировать» правила таким образом, что они вновь не будут работать.

В данных условиях, мной видится решение проблемы, в изменении самого подхода к выполнению работ по ТО ВДГО.

Во-первых, должно быть введено государственное регулирование цен на работы, выполняемые в рамках ТО ВДГО. Тарифным регулятором может выступить как федеральная антимонопольная служба, так и региональные тарифные органы.

Во-вторых, работы должны выполняться специализированными организациями без взимания платы с населения. Стоимость работ, определенная регулятором должна быть включена в стоимость газа и взиматься однократно поставщиком газа по договору поставки газа. В свою очередь Поставщик газа заключает договоры со специализированными организациями на выполнение ТО ВДГО.

В-третьих, необходимо введение требований к специализированным организациям (наличие персонала и ресурсов, страхование ответственности и т.п.), которые смогут осуществлять деятельность в сфере ТО ВДГО, например, посредством ее лицензирования. ТО ВДГО связано с использованием источника повышенной опасности - природного газа, известного своими взрыво и пожароопасными свойствами. В научной литературе отмечено, что осуществление предпринимательской деятельности, сопряженной с имущественными рисками, обусловливает объективную заинтересованность хозяйствующих субъектов в предупреждении негативных последствий ее осуществления [3]. Эффективным решением данной задачи является именно страхование, как важнейший фактор снижения убытков организаций и источник для реальной выплаты пострадавшим. При этом, страхование в сфере ТО ВДГО должно быть обязательным, а не добровольным, как в настоящее время.

Кроме этого, необходимо отметить, что обеспечение безопасной и безаварийной эксплуатации ВДГО посредством лишь его технического обслуживания является недостаточным. Своевременная диагностика газового оборудования, его замена, выполнение ремонтных работ, надлежащее обслуживание и ремонт домовых вентиляционных каналов, все это, в совокупности, необходимо для того, чтобы газоснабжение являлось лишь средством комфортного проживания. В настоящее время все эти виды работ обращаются на открытом рынке, с его плюсами и минусами. Население, в значительной своей массе оказалось недостаточно готовым к тому, что ему предлагает рынок: самостоятельный выбор из множества организаций (среди которых находятся недобросовестные участники рынка), отсутствие реального контроля со стороны надзорных органов, массовые нарушения обязательств всеми участниками рынка и т.д. Учитывая изложенное, предложения по изменению законодательства, указанные выше, являются обоснованными и актуальными.

$$
* * *
$$

1. Решение Верховного Суда РФ от 10.12.2013 N АКПИ13-826;

2. Информационное агентство «Высота $102 » / /$ « новостройке в Волгограде вспыхнул газ: три человека в больнице» // URL:https://v102.ru/news/91901.html;

3. Романова И.Н. Страхование в сфере предпринимательской деятельности как редуцирующий фактор убытков // Legal Concept = Pravovaya paradigma. 2019, Vol. 18, No. 2 // https://doi.org/10.15688/lc.jvolsu.2019.2.12. 